\title{
Effect of Dissolved Oxygen and Inoculum Concentration on Xylose Reductase Production from Candida guilliermondii Using Sugarcane Bagasse Hemicellulosic Hydrolysate
}

\author{
Thais Suzane dos Santos Milessi, Anuj Kumar Chandel, Ricardo de Freitas Branco, \\ Sílvio Silvério da Silva* \\ Department of Biotechnology, Engineering School of Lorena, University of São Paulo, Estrada Municipal do Campinho s/n, Lorena, \\ Brazil. \\ Email: thais.milessi@gmail.com
}

Received January 20 ${ }^{\text {th }}, 2011$; Revised February $20^{\text {th }}, 2011$; Accepted March $28^{\text {th }}, 2011$.

\begin{abstract}
This work evaluated the effect of dissolved oxygen and the initial inoculum concentration on xylose reductase (XR) production by Candida guilliermondii from sugarcane bagasse hemicellulosic hydrolysate. Both the parameters were studied under an experimental design $2^{2}$ with triplicate at central point. The statistical analysis of the results indicated a significant negative effect on XR production from the variable inoculum. The variable dissolved oxygen also showed a negative effect on XR production. We found the maximum enzyme activity $\left(2.5 \mathrm{U} \cdot \mathrm{mg}^{-1}\right)$ when both the factors were applied at their lowest levels. The yeast showed to be potentially capable for xylose reductase production when sugarcane bagasse hemicellulosic hydrolysate was used as carbon source. Also, the results presented important information for further optimization of xylose reductase attainment.
\end{abstract}

Keywords: Xylose Reductase, Sugarcane Bagasse, Candida guilliermondii, Experimental Design

\section{Introduction}

D-xylose is the most abundant five carbon sugar in nature and is one of the major constituent mono- saccharide in plant cell wall $[1,2]$. Xylose reductase (XR, E.C. 1.1.1.21), a pentose reductase which catalyses the first step of five carbon metabolism by reducing xylose into xylitol with $\mathrm{NAD}(\mathrm{P}) \mathrm{H}$ as donor of hydrogen atoms $[3,4]$ and is dependent of the coenzyme nicotinamide adenine dinucleotide phosphate form, NADPH $[5,6]$. XR have gained interest because of its importance in the conversion of xylose into xylitol in vitro. Xylitol is then converted into $\mathrm{D}$-xylulose for ethanol production by pentose phosphate pathway $[7,8]$.

Xylitol is a polyol important for food, dental and pharmaceutical industries because of its properties like sweetener capacity, metabolism independent of insulin and anti-carcinogenic properties [9-12]. The disad- vantages in conventional processes for xylitol production, such as purification steps with low efficiency and pro-ductivity, alternative routes such as XR- mediated conversion processes have been found more promising for xilitol production in shorter times with high productivities $[6,13]$.

Many yeast strains produce high yields of xylitol from xylose rich hydrolysates of lignocellulosic materials [14]. However, for a successful xylitol production by enzymatic routes, it is necessary to optimize the XR production in fermentation reactions. Therefore, studies about XR production are necessary to understand the influence of process variables to get the satisfactory yields of XR. Inoculum concentration and dissolved oxygen levels are the two most important factors which influence the optimum XR production from a variety of microor- ganisms [14-16]. In yeasts, oxygen supply affects the rate and yield of xilitol and ethanol which determines the portioning of the carbon flux from xylose between cell growth and product formation [17].

Gurpilhares et al. (2005) observed the significant influence of inoculum concentration on Glucose-6-phos- 
phate dehydrogenase production from C. guilliermondii, which is also an intracellular enzyme. Branco et al. (2009) showed the possibility of the oxygen availability interference on XR production.

In the present work, inoculum level and the dissolved oxygen were studied in order to verify their effect on XR production by the yeast C. guilliermondii FTI 20037 using sugarcane bagasse hemicellulosic hydrolysate under an experimental design $2^{2}$ with triplicate at central point.

\section{Material and Methods}

\subsection{Microorganism and Inoculum}

The yeast C. guilliermondii FTI 20037 was maintained on malt-extract agar slants at $4^{\circ} \mathrm{C}$.

It was cultivated in $125 \mathrm{~mL}$ Erlenmeyer flasks containing $50 \mathrm{~mL}$ of synthetic medium with $30 \mathrm{~g} \cdot \mathrm{L}^{-1}$ of $\mathrm{xy}-$ lose, $3 \mathrm{~g} \cdot \mathrm{L}^{-1}$ of ammonium sulfate, $0.1 \mathrm{~g} \cdot \mathrm{L}^{-1}$ of calcium chloride and $10 \% \mathrm{v} / \mathrm{v}$ of rice bran extract [18]. The inoculum was grown in shake flasks for 24 hours at $30^{\circ} \mathrm{C}$ and $200 \mathrm{rpm}$. Thereafter, it was recovered by centrifugation at $2000 \mathrm{xg}$ for 20 minutes, washed and resuspended in water to obtain a high cell density suspension.

\subsection{Sugarcane Bagasse Hydrolysis}

The bagasse was provided by Companhia Açucareira Vale do Rosário located in Orlândia-SP, Brasil. The hydrolysate was obtained in inox reactor with capacity for $30 \mathrm{~L}$ located in the Department of Biotechnology of EEL-USP, Lorena, São Paulo, Brazil.

For the hydrolysis of the sugarcane bagasse, $\mathrm{H}_{2} \mathrm{SO}_{4}$ ( $98 \%$ of purity) was used as catalyst in a ratio of $100 \mathrm{mg}$ of acid/g of dry matter, during 20 minutes at $121^{\circ} \mathrm{C}$, using a ratio of $1 / 10$ between the bagasse mass and the volume of acid solution [19]. The hydrolysate obtained was maintained at $4^{\circ} \mathrm{C}$. For fermentation reactions, the hydrolysate was supplemented with the medium ingredients as the same described elsewhere.

\subsection{Detoxification of Sugarcane Bagasse Hydrolysate}

The hemicellulosic hydrolysate was concentrated at $70^{\circ} \mathrm{C}$ in a concentrator with capacity for $32 \mathrm{~L}$ to obtain a xylose concentration of $30 \mathrm{~g} \cdot \mathrm{L}^{-1}$ in the final hydrolysate. The concentrated hydrolysate was detoxified according to Alves et al. (1998), which consists of three phases: Raising the $\mathrm{pH}$ to 7.0 with calcium oxide $(\mathrm{CaO})$; reduction of $\mathrm{pH}$ to 5.5 with phosphoric acid $\left(\mathrm{H}_{3} \mathrm{PO}_{4}\right)$; and addition of activated charcoal in a ratio of $2.5 \% \mathrm{w} / \mathrm{v}$, the mixture was kept in a rotatory shaker at $200 \mathrm{~min}^{-1}$ and $30^{\circ} \mathrm{C}$ for 1 hour. After each stage of processing, the hydrolysate was filtered under vacuum and after the last phase it was auto- claved under $0.5 \mathrm{~atm}\left(110^{\circ} \mathrm{C}\right)$ for 15 minutes [20].

\subsection{Xylose Reductase Production}

The fermentation runs were performed in batch bio- reactor BIOFLO III 1.25 L (New Brunswick Scientific Co. Inc., Edison, New Jersey, USA) at $30^{\circ} \mathrm{C}, \mathrm{pH} 5.5$, aeration of $1.0 \mathrm{vvm}$ and an initial xylose concentration of $30 \mathrm{~g} \cdot \mathrm{L}^{-1}$. The fermentation reactions were carried out until $24 \mathrm{hrs}$. The samples were collected after every $6 \mathrm{hrs}$ and freezed for their analysis for the production of XR, xilitol, biomass and left over sugars in the medium.

\subsection{Enzymatic Extract Attainment}

The enzyme was attainment by cell disruption under vortex agitation using glass pearls $(0.5 \mathrm{~mm}$ diameter $)$ according to conditions previously determined by [21]. After fermentation, the cells were harvested by centrifugation at $2000 \mathrm{xg}$, washed with sterile distilled water, centrifuged and resuspended in $0.071 \mathrm{M}$ Tris- $\mathrm{HCl}$ buffer, pH: 7.5 resulting in a cell suspension with determined concentration $\left(3 \mathrm{~g} \cdot \mathrm{L}^{-1}\right)$. These suspensions were mechanically disrupted in centrifuge tubes under vortex agitation using glass beads. Aliquots of $3 \mathrm{~mL}$ of cell suspension were added with $3 \mathrm{~mL}$ of glass beads (propor- tion of $1: 1, \mathrm{v} / \mathrm{v}$ ) in a centrifuge tube under vortex agitation at regular time $(5 \mathrm{~min})$. The disruption period was $1 \mathrm{~min}$ separated by $30 \mathrm{~s}$ interval in an ice bath. The samples were then centrifuged at $10000 \mathrm{xg}, 15 \mathrm{~min}, 5^{\circ} \mathrm{C}$ (Jouan, Model BR 4i, St. Herblain, France) and the supernatants were assayed for enzyme activity (XR) and protein concentration.

\subsection{Enzymes Activity Determination}

XR activity was determined according to Branco et al. (2009) by spectrophotometric analysis (Beckman DU 640B spectrophotometer, Fullerton, CA, USA), using $\mathrm{NADPH}$ as the detecting parameter at $25^{\circ} \mathrm{C}$ and $340 \mathrm{~nm}$, in a medium composed shown in Table $\mathbf{1}$. The activity was calculated from the slope of the absorbance versus the time curve by using the apparent molar extinction coefficient of $6.22 \mathrm{mmol}^{-1} \cdot \mathrm{cm}^{-1}$ for NAD (P) H. One XR unit $(\mathrm{U})$ was defined as the amount of enzyme that catalyzes the oxidation of $1 \mu \mathrm{mol}$ of cofactor per minute at $25^{\circ} \mathrm{C}$. The specifics activities were expressed in units per milligram of total protein $\left(\mathrm{U} \cdot \mathrm{mg}^{-1}\right)$. The total proteins analysis was done according to Bradford method.

\subsection{Experimental Design for Inoculum and the Dissolved Oxygen Level Study}

Experiments according to a $2^{2}$ full factorial design with triplicate at center point were carried out in order to evaluate the effect of dissolved oxygen and initial cells 
Table 1. Reaction medium to the Xylose reductase analysis.

\begin{tabular}{cc}
\hline Reagents & $(\mu \mathrm{L})$ \\
\hline Tris buffer (71 mM, pH 7.2) & 350 \\
NADPH (1.2 mM) & 50 \\
Xylose (2.0 M) & 50 \\
Enzymatic Extract & 150 \\
Final Volume & 600 \\
\hline
\end{tabular}

*The blank solution was determined with distillated water.

concentration on XR production. The dissolved oxygen levels were $20 \%(-1)$ and $50 \%(+1)$ of the maximum oxygen concentration in solution, and the inoculum concentration were the following: $1.0 \mathrm{~g} \cdot \mathrm{L}^{-1}(-1)$ and 4.0 $\mathrm{g} \cdot \mathrm{L}^{-1}(+1)$. The highest specific activity of XR was considered as response variable.

\subsection{Determination of Reaction Media Components}

The concentration of free cells was determined by turbidimetry with a Beckman DU 640 B spectro- photometer (Fullerton, CA, USA), at wavelength $600 \mathrm{~nm}$ and correlated with the dry weight of cells $\left(\mathrm{g} \cdot \mathrm{L}^{-1}\right)$ through a calibration curve. The measurements were made on diluted cell suspensions, after centrifugation, washing and resuspension of cells in distilled water.

The determination of the xylose concentrations was verified by high performance liquid chromatography (HPLC) in chromatograph Schimadzu LC-10 AD (Kyoto, Japan) with column equipped with BIO-RAD Aminex HPX-87H $(300 \times 7.8 \mathrm{~mm})$ coupled to a detector of refractive index RID-6A, with eluent $0.01 \mathrm{~N}$ sulfuric acid at a flow rate of $0.6 \mathrm{~mL} \cdot \mathrm{min}^{-1}$, column temperature of $45^{\circ} \mathrm{C}$ and injected volume of $20 \mu \mathrm{L}$. Before the readings in the column, the samples were filtered through Sep Pak C18 filter.

\section{Results and Discussion}

Procedures for enzymes attainment have become very important because they have gained importance in several applied areas. Among them, production of XR and further its application in xilitol production has been little investigated. To contribute the knowledge on the production of XR, fermentation tests were performed according to a complete $2^{2}$ factorial design with triplicate in the central point to value the effect of dissolved oxygen availability and inoculums concentration. The experimental design matrix along with the maximum XR specific activity in each experiment is shown in Table 2.

\subsection{Effect of Inoculum on XR Production}

The effect of inoculum in XR production was investigated within the range of $1.0-4.0 \mathrm{~g} \cdot \mathrm{L}^{-1}$ of cells. Table 2 shows that maximum XR production $\left(2.5 \mathrm{U} \cdot \mathrm{mg}^{-1}\right.$ of protein) was obtained with the negative level of inocu- lum $\left(1.0 \mathrm{~g} \cdot \mathrm{L}^{-1}\right)$. Our results are in well accordance with the findings of Roberto et al. (1996) who observed that the inoculum increase had a negative effect on the xylitol production from rice straw hemicellulose hydrolysate by C. guilliermondii. As xylose reductase is the enzyme responsible for D-xylose/xylitol conversion, the effect of inoculum on XR production could also be negative.

The inoculum effect was negative in this study and it indicates that the appropriate level to this variable is the lowest $(-1)$ using $1.0 \mathrm{~g} \cdot \mathrm{L}^{-1}$ as initial cells concentration. Gurpilhares et al. (2005) also obtained the similar results regarding the significance of the inoculum on the production of glucose-6-phosphate dehydrogenase with the negative level of inoculum $\left(1.0 \mathrm{~g} \cdot \mathrm{L}^{-1}\right)$. This could have been caused by the high availability of xylose to the cells. It is known that the presence of xylose in the culture

Table 2. Factorial design $2^{2}$ and XR maximum specific activity.

\begin{tabular}{|c|c|c|c|c|c|}
\hline \multirow{2}{*}{ Experiment } & \multicolumn{2}{|c|}{ Initial Inoculum } & \multicolumn{2}{|c|}{ Dissolved Oxygen } & \multirow{2}{*}{$\begin{array}{l}\text { XR maximum specific } \\
\text { activity }\left(\mathrm{U} \cdot \mathrm{mg}^{-1}\right)\end{array}$} \\
\hline & Coded Value & Real Value $\left(\mathrm{g} \cdot \mathrm{L}^{-1}\right)$ & Coded Value & Real Value (\%) & \\
\hline 1 & -1 & 1 & -1 & 20 & 2.5 \\
\hline 2 & -1 & 1 & +1 & 50 & 2.0 \\
\hline 3 & +1 & 4 & +1 & 50 & 1.8 \\
\hline 4 & +1 & 4 & -1 & 20 & 1.3 \\
\hline 5 & 0 & 2.5 & 0 & 35 & 1.1 \\
\hline 6 & 0 & 2.5 & 0 & 35 & 1.3 \\
\hline 7 & 0 & 2.5 & 0 & 35 & 1.2 \\
\hline
\end{tabular}


medium induces the XR production [22]. However, still little is known about the regulatory mechanism of intracellular enzymes production with the effect of sugars available to the microorganisms.

Silva et al. (2005) observed that in fermentative process the inoculum could influence the XR obtained. They tested different inoculums grown in glucose, xylose and glucose and xylose and concluded that the better XR production $\left(0.582 \mathrm{U} \cdot \mathrm{mg}^{-1}\right)$ was with the cells grown in glucose/xylose medium.

\subsection{Effect of Dissolved Oxygen on XR Production}

The effect of dissolved oxygen on XR production has been presented in Table 2. The maximum XR production (2.5 U.mg ${ }^{\mathrm{v} 1}$ of protein) was obtained with the negative level of dissolved oxygen (20\%) and that the enzymatic activity decreased with high values of dissolved oxygen. Earlier, Kim et al. (1997) observed the importance of dissolved oxygen control on xylitol production and consequently on XR activity. Branco et al. (2009) studied the influence of oxygen transfer volumetric coefficient $\left(K_{L} a\right)$ on xylose reductase and xylitol dehydrogenase activity and observed that the high $\mathrm{XR}$ rate $\left(1.45 \mathrm{U} \cdot \mathrm{mg}^{-1}\right)$ was obtained in the experiment using the low value of $K_{L} a$. According to them, the maximum XR activity decreased with the increase of the $K_{L} a$. This could be probably due to a deviation of the yeast metabolism from xylitol to biomass, because, when the cells are stimulated to grow (in this case through high oxygen availability), they tend to produce more amino acids, enzymes and proteins.

\subsection{Statistics Analysis}

It was observed that the most appropriate test to obtain the XR is the test with levels $-1,-1\left(1 \mathrm{~g} \cdot \mathrm{L}^{-1}\right.$ of initial inoculum and $20 \%$ of dissolved oxygen). The statistical analysis of the experimental design is presented in Table 3, along with the values of the effects of each input variable and the interaction between them.

The dissolved oxygen (X2) was not significant in this study. It is observed that inoculum (X1) was the input variable that most influenced XR production, followed by the interaction of variables. The interaction was consistent with the results of main effects, which is posi- tive since the variables 1 and 2 had negative effects. Thus, the interaction of levels $-1,-1$ benefited the production of XR.

Table 4 presents the analysis of variance for a linear model for the experimental design. It was observed that the curvature was significant, indicating that the behavior of the response variable is not linear. This was evidenced by the significant lack of fit, which indicates that the linear model proposed is not adequate to explain the dependent variable (specific activity) in the study zone. The consumption of xylose, the growth of biomass and XR specific activity observed in the fermentation ran in the lowest levels are detailed on Figures $\mathbf{1}$ and 2. It is interesting to underline that the highest specific activity of XR was observed between 10 and 12 hours of fermen- tation, and such behavior was observed in all trials conducted in complete factorial design.

Table 3. Effects and significance values to the input variables in XR specific activity.

\begin{tabular}{ccccc}
\hline & Effect & Deviation & $\mathrm{t}(2)^{*}$ & $\mathrm{P} * *$ \\
\hline Average & 1.888 & 0.050 & 37.750 & 0.001 \\
$\mathrm{X}_{1}$ & -0.725 & 0.100 & -7.250 & 0.018 \\
$\mathrm{X}_{2}$ & -0.025 & 0.100 & -0.250 & 0.826 \\
$\mathrm{X}_{1} \cdot \mathrm{X}_{2}$ & 0.475 & 0.100 & 4.750 & 0.042 \\
\hline *Test t of student for two degrees of freedom; **Test $\mathrm{p}$ for $95 \%$ of trust.
\end{tabular}

Table 4. Analysis of variance (ANOVA) for a linear model.

\begin{tabular}{ccccc}
\hline & SS & Df & MS & P \\
\hline Curvature & 0.810 & 1 & 0.810 & 0.012 \\
Inoculum (1) & 0.526 & 1 & 0.526 & 0.018 \\
Interaction 1-2 & 0.226 & 1 & 0.226 & 0.042 \\
Lack of fit & 0.810 & 1 & 0.810 & 0.012 \\
Pure Error & 0.020 & 2 & 0.010 & \\
Total SS & 1.582 & 6 & & \\
\hline
\end{tabular}

SS square sum; Df degree of freedom; Ms mean square; $\mathrm{P} p$ factor.

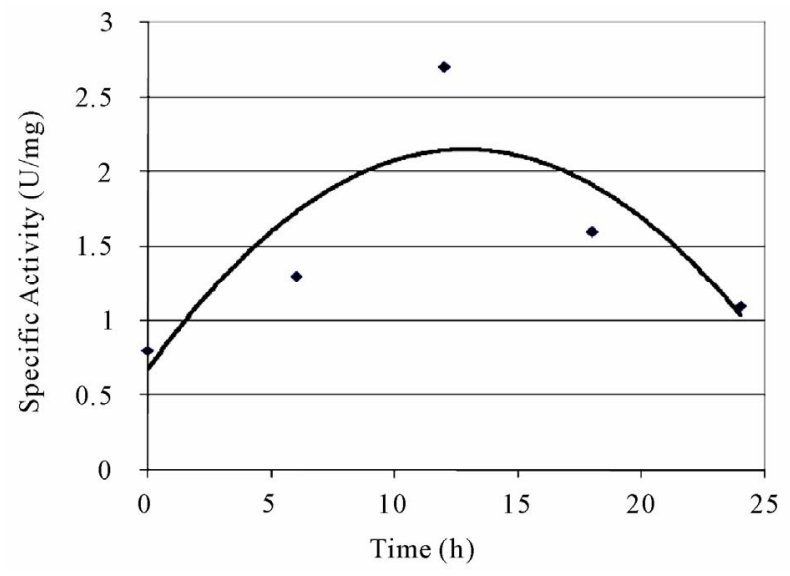

Figure 1. XR specific activity in fermentation $-1 ;-1\left(1 \mathrm{~g} \cdot \mathrm{L}^{-1}\right.$ of inoculum and $20 \%$ of dissolved oxygen. 


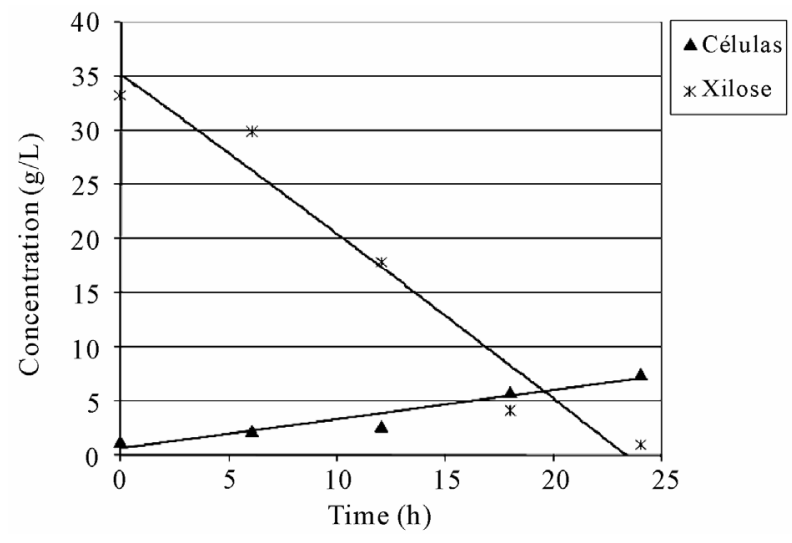

Figure 2. Xylose concentration and biomass growth during the fermentative process.

\section{Conclusions}

The initial concentration of inoculum is an important factor in the production of xylose reductase, interfering significantly in this process, as well as its combination with an appropriate percentage of dissolved oxygen. These evidences led to increase awareness of important parameters in the search for optimal production of xylose reductase and the feasibility of enzymatic production of xylitol, which is still a challenge in biotechnology.

\section{Acknowledgements}

Authors are grateful to the CNPq, FAPESP and USPEEL for the financial support for this work.

\section{REFERENCES}

[1] S. Fernandes, M. G. Tuohy and P. G. Murray, "Xylose Reductase from the Thermophilic Fungus Talaromyces Emersonii: Cloning and Heterologous Expression of the Native Gene (Texr) and a Double Mutant (TexrK271R + N273D) with Altered Coenzyme Specificity," Journal of Bioscience, Vol. 34, No. 6, 2009, pp. 881-890. doi:10.1007/s12038-009-0102-7

[2] A. K. Chandel, M. L. Narasu, R. Rudravaram, R. Pogaku and L. V. Rao, "Bioconversion of De-Oiled Rice Bran (DORB) Hemicellulosic Hydrolysate into Ethanol by Pichia Stipitis NCM3499 under Optimized Conditions," International Journal of Food Engineering, Vol. 5, No. 1, 2009, p. 8. doi:10.2202/1556-3758.1453

[3] S. M. A. Rosa, M. G. A. Felipe, S. S. Silva and M. Vitolo, "Xylose Reductase Production by Candida guilliermondii," Applied Biochemistry and Biotechnology, Vol. 70, No. 72, 1998, pp. 127-135. doi:10.1007/BF02920130

[4] O. V. Dmytruk, K. V. Dmytruk, C. A. Abbas, A. Y. Voronovsky and A. A. Sibirny, "Engineering of Xylose Reductase and Overexpression of Xylitol Dehydrogenase and Xylulokinase Improves Xylose Alcoholic Fermentation in the Thermotolerant Yeast Hansenula polymor- pha," Microbial Cell Factories, Vol. 7, No. 21, 2008, p. 21. doi:10.1186/1475-2859-7-21

[5] N. J. Alexander, "Temperature Sensitivity of the Induction of Xylose Reductase in Pachysolen tannophilus," Biotechnology and Bioengineering, Vol. 27, No. 12, 1985, pp. 1739-1744. doi:10.1002/bit.260271218

[6] R. F. Branco, J. C. Santos, A. Pessoa Jr. and S. S. Silva, "Profiles of Xylose Reductase, Xylitol Dehydrogenase and Xylitol Production under Different Oxygen Transfer Volumetric Coefficient Values," Journal of Chemical technology and biotechnology, Vol. 84, No. 3, 2009, pp. 326- 330. doi: $10.1002 /$ jetb. 2042

[7] R. Woodyer, M. Simurdiak, W. A. V. D. Donk and H. Zhao, "Heterologous Expression, Purification and Characterization of a Highly Active Xylose Reductase from Neurospora Crassa," Applied and Enviromental Microbiology, Vol. 71, No. 3, 2004, pp. 1642-1647. doi:10.1128/AEM.71.3.1642-1647.2005

[8] O. Bengtsson, B. Hahn-Hägerdal and M. F. GorwaGrauslund, "Xylose Reductase from Pichia stipitis with Altered Coenzyme Preference Improves Ethanolic Xylose Fermentation by Recombinant Saccharomyces cerevisae," Biotechnology for Biofuels, Vol. 2, No. 9, 2009, p. 10.

[9] D. B. Gurpilhares, A. Pessoa Jr. and I. C. Roberto, "Glucose-6-phosphate Dehydrogenase and Xylitol Production by Candida guilliermondii FTI 20037 Using Statistical Experimental Design," Process Biochemistry, Vol. 41, No. 3, 2005, pp. 631-637. doi:10.1016/j.procbio.2005.08.008

[10] J. M. Marton, M. G. A. Felipe, J. B. A. e Silva and A. Pessoa Júnior, "Evaluation of the Activated Charcoals and Adsorption Conditions Used in the Treatment of Sugarcane Bagasse Hydrolysate for Xylitol Production," Brazilian Journal of Chemical Engineering, Vol. 23, No. 1, 2006, pp. 9-21. doi:10.1590/S0104-66322006000100002

[11] J. P. Mikkola, T. Salmi, A. Villela, H. Vainio, P. Mäki-Arvela, A. Kalantar, T. Ollonqvist, J. Väyrynem and R. Sjöholm, "Hydrogenation of Xylose to Xylitol on Sponge Nickel Catalyst-A Study of the Process and Catalyst Deactivation Kinetics," Brazilian Journal of Chemical Engineering, Vol. 20, No. 3, 2003, pp. 263271. doi:10.1590/S0104-66322003000300006

[12] M. F. Gliemmo, A. M. Calvin, O. Tamasib, L. N. Gerschensona and C. A. Camposa, "Interactions between Aspartame, Glucose and Xylitol in Aqueous Systems Containing Potassium Sorbate," LWT-Food Science and Technology, Vol. 41, No. 4, 2008, pp. 611-619.

[13] E. Winkelhausen and S. Kusmanova, "Microbial Conversion of D-Xylose to Xylitol," Journal of Fermentation and Bioengineering, Vol. 86, No. 1, 1998, pp. 1-14. doi:10.1016/S0922-338X(98)80026-3

[14] R. S. Prakasham, R. S. Rao and P. J. Hobbs, "Current Trends in Biotechnological Production of Xylitol and Future Prospects," Current Trends in Biotechnology and 
Pharmacy, Vol. 3, No. 1, 2009, pp. 8-36.

[15] I. C. Roberto, S. Sato and I. M. Mancilha, "Effect of Inoculum Level on Xylitol Production from Rice Straw Hemicellulose Hydrolysate by Candida guilliermondii," Journal of Industrial Microbiology, Vol. 16, No. 16, 1996, pp. 348-350. doi:10.1007/BF01570113

[16] D. D. V. Silva and M. G. A. Felipe, "Effect of Glucose:Xylose Ratio on Xylose Reductase and Xylitol Dehydrogenase Activities from Candida guilliermondii in Sugarcane Bagasse Hydrolysate," Journal of Chemical Technology and Biotechnology, Vol. 81, No. 7, 2006, pp. 1295-1300.

[17] S. Kim, J. Kim and D. Oh, "Improvement of Xylitol Production by Controlling Oxygen Supply in Candida parapsilosis," Journal of Fermentation and Bioengineering, Vol. 83, No. 3, 1997, pp. 267-270. doi:10.1016/S0922-338X(97)80990-7

[18] R. F. Branco, J. C. Santos, L. Y. Murakami, S. I. Mussato, G. Dragone and S. S. Silva, "Xylitol Production in a Bubble Column Bioreactor: Influence of the Aeration Rate and Immobilized System Concentration," Process Biochemistry, Vol. 42, No. 2, 2007, pp. 258-262.

[19] D. D. V. Silva, M. G. A. Felipe, I. M. Mancilha and S. S. Silva, "Evaluation of Inoculum of Candida guillier- mondii Grown in Presence of Glucose on Xylose Reductase and Xylitol Dehydrogenase Activities and Xylitol Production during Batch Fermentation of Sugarcane Bagasse Fermentation," Applied Biochemistry and Biotechnnology, Vol. 121-124, No. 1-3, 2005, pp. 427-437. doi:10.1385/ABAB:121:1-3:0427

[20] L. A. Alves, M. G. A. Felipe, J. B. A. Silva, S. S. Silva and A. M. R. Prata, "Pre-Treatment of Sugarcane Bagasse Hemicellulose Hydrolisate for Xylitol Production by Candida guilliermondii," Applied Biochemistry and Biotechnology, Vol. 70-72, No. 1, 1998, pp. 89-98. doi:10.1007/BF02920126

[21] D. B. Gurpilhares, F. A. Hasmanna, A. Pessoa Jr. and I. C. Roberto, "Optimization of Glucose-6-phosphate Dehydrogenase Releasing from Candida guilliermondii by Disruption with Glass Beads," Enzyme and Microbial Technology, Vol. 39, No. 4, 2006, pp. 591-595. doi:10.1016/j.enzmictec.2005.11.018

[22] S. I. Mussatto and I. C. Roberto, "Establishment of the Optimum Initial Xylose Concentration and Nutritional Supplementation of Brewer's Spent Grain Hydrolysate for Xylitol Production by Candida guilliermondii," Process Biochemistry, Vol. 43, No. 5, 2008, pp. 540-546. doi:10.1016/i.procbio.2008.01.013 